A N NALES

UNIVERSITATIS MARIAE CURIE-SKŁODOWSKA LUBLIN - POLONIA

VOL. LXXI, z. 2

SECTIO B

2016

Pracownia Dydaktyki Geografii, Wydział Oceanografii i Geografii, Uniwersytet Gdański 80-309 Gdańsk, ul. Bażyńskiego 8; geotso@ug.edu.pl

TERESA SADOŃ-OSOWIECKA

\title{
Między mądrością a potocznością edukacji geograficznej. Przykład brytyjski
}

Between wisdom and ordinariness of geographical education. British case

\begin{abstract}
Słowa kluczowe: edukacja geograficzna, mądrość, potoczność, progresywizm, wiedza dająca moc
\end{abstract}

Keywords: geographical education, wisdom, naive knowledge, progressivism, powerful knowledge

\section{KATEGORIA MĄDROŚCI A KATEGORIA POTOCZNOŚCI}

Edukacja od czasów starożytnych jest zawsze, przynajmniej deklaratywnie, skierowana ku czynieniu świata bardziej zrozumiałym, a dzięki temu ku sprawianiu, by życie edukowanych ludzi było lepsze. Ważną kategorią, która pojawiła się we współczesnych tekstach dotyczących edukacji stosunkowo niedawno, choć zawsze powinna towarzyszyć refleksji o kształceniu, jest kategoria mądrości (wisdom), trudno definiowalna, nieuchwytna w ściśle naukowy, obiektywistyczny sposób, a polegająca na totalnym, holistycznym rozumieniu świata (total understanding) (Sternberg 1990). Według Sternberga (1990) oraz Csikszentmihalyi i Rathunde (1990) mądrość może być ujmowana na trzy sposoby:

- jako proces poznawczy (cognitive process), który polega na próbie zrozumienia świata $\mathrm{w}$ sposób bezstronny, związany z poszukiwaniem podstawowych przyczyn i konsekwencji zdarzeń, prowadzący do integracji wiedzy (Sternberg 1990); droga do wiedzy, sposób poznawania czy sposób, w jaki się coś wie (way of knowing) raczej, niż samo pojęcie wiedzy (knowledge), choć zawierający uniwersalne prawdy; polegający nie na 
samej rejestracji faktów, ale na obserwowaniu aspektów rzeczywistości we wzajemnych relacjach (Csikszentmihalyi, Rathunde 1990) i próbach zrozumienia ich;

- jako moc sprawcza zmuszająca do podejmowania działania (a virtue providing a compelling guide to action) (Sternberg 1990) lub jako społecznie wartościowany wzór zachowania (socially valued pattern of behaviour) w holistycznym, systemowym ujęciu (Csikszentmihalyi, Rathunde 1990), biorącym pod uwagę relacje między zjawiskami. Dzięki mądrości staje się możliwa poprawa naszego życia poprzez zrozumienie, jak lepiej kierować naszymi działaniami, by żyć w harmonii z prawami otaczającego świata (Sternberg 1990);

- jako dobro osobiste, rozumiane jako stan wewnętrzny doświadczania satysfakcji i zadowolenia, wynikający z osobistej, wielopłaszczyznowej, bezstronnej refleksji nad związkami między zdarzeniami (Sternberg 1990); rodzaj wewnętrznej radości płynącej z odkrywania i poznawania; mądrość w tym ujęciu jest użyteczna dla indywidualnej osoby tu i teraz.

Wszystkie te trzy aspekty mądrości nasuwają skojarzenia ze znanym z dokumentów edukacyjnych wydzieleniem wiedzy, umiejętności i postaw. W tym wypadku jednak nie da się ich oddzielić. Są ze sobą związane i łącznie prowadzą do rozumienia mądrości jako ich splotu. Mądrość nie jest ich sumą, ale nową jakością dzięki traktowaniu jej aspektów łącznie we wzajemnych relacjach. Nie są one wartościujące, ale implikują pewną hierarchię prawd i działań dzięki tym prawdom podejmowanym (Csikszentmihalyi, Rathunde 1990). W takim ujęciu mądrość może sprzyjać adaptacji wielokulturowej, a tym samym tolerancji i szacunkowi dla odmienności, zapobiegając konfliktom, także zbrojnym; mówiąc górnolotnie słowami amerykańskich psychologów - sprzyjać przetrwaniu i rozwojowi ludzkości. Mądrość może stać się także głównym mechanizmem ewolucji kulturowej i alternatywą dla płytkiej kultury opartej na zewnętrznej satysfakcji, wynikającej z doraźnych, materialnych przyjemności (Csikszentmihalyi, Rathunde 1990) i, dodam, z krótkotrwałej satysfakcji płynącej z uzyskiwania dobrych ocen szkolnych na podstawie łatwo przyswajalnych, jednoznacznych wiadomości (wiadomości właśnie, a nie - wiedzy). Mogłaby zatem odegrać znaczącą rolę w zmianie edukacji, będąc medium realizacji uniwersalnych jej celów.

Warto zwrócić uwagę na paradoks, polegający na tym, że jeśli nie będziemy odróżniać mądrości od innych form wiedzy, jeśli nie będziemy myśleć głębiej o niej i jeśli zaakceptujemy jej wartość jako narzuconą odgórnie, bez kwestionowania, prawdopodobnie nie będziemy zdolni jej używać (Csikszentmihalyi, Rathunde 1990). Mądrość wymaga ciągłego namysłu, wahania, rozpatrywania różnych punktów widzenia. Nie daje prostych odpowiedzi. 
Mądrość korzysta zarówno z wiedzy naukowej, jak i z wiedzy potocznej („,zdroworozsądkowej” - naive knowledge, folk knowledge), która, jak twierdzą współcześni badacze, tworzona jest podobnie jak naukowa (por. np.: Chalmers 1993) i którą wykorzystują naukowcy do tworzenia nowych koncepcji, zwłaszcza w naukach społecznych (por. np.: Bauman 1996; Hołówka 1986). Ważne jest nie tyle samo jej używanie, co przede wszystkim świadomość korzystania z wiedzy potocznej w nauce (Klus-Stańska 2010). Oba rodzaje wiedzy cechuje intuicyjność. W wielkim uproszczeniu (można by powiedzieć - potocznie) tworzenie obu rodzajów wiedzy polega najpierw na obserwacji oraz rejestracji zjawisk i faktów, próbie ich wyjaśnienia, łączenia i zrozumienia, a następnie na generalizacji w postaci ogólnych praw czy przekonań oraz ciągłym badaniu ich prawdziwości. Ważna jest także jej kontekstualność. Jednak sama wiedza, różnie sytuowana w różnych kulturach, nie jest tożsama z mądrością, choć jest jej nieodzownym elementem (zob.: Takahashi, Overton 2005).

Potoczność jako pojęcie usytuowane jednak jest w tym artykule na przeciwstawnym biegunie niż mądrość. Nie ma ono w tym wypadku wiele wspólnego ze „zdrowym rozsądkiem”, który może być elastyczny, krytyczny i dzięki któremu może być budowana swoista wiedza. Wiąże się z uproszczoną wizją świata. Potoczność w tym wypadku, w przeciwieństwie do mądrości, wynika z braku refleksji nad przyjmowanymi, odgórnie narzucanymi, ,prostymi” rozwiązaniami i ich dalekosiężnymi skutkami, z nieświadomości założeń leżących u ich podstaw, co uniemożliwia krytyczny namysł. Jest zafiksowana na jednym ustalonym sposobie ujmowania świata $i$, w przeciwieństwie do mądrości, która rozpatruje zjawiska w zależności od kontekstu, nie przyjmuje innych, relatywizujących interpretacji. Potoczność jest cechą „edukacyjnej przestrzeni mitycznej”, w której dominują mity - utarte stereotypy na temat istoty edukacji i kształcenia silnie zakorzenione społecznie, ale niemające żadnego uzasadnienia naukowego (Ledzińska, Czerniawska 2011).

Opiniom, sądom i nastawieniom w potocznym myśleniu nadaje się status faktów (Klus-Stańska 2010). Wiedza potoczna stanowi „podstawę automatycznego nadawania znaczeń dziejącym się wydarzeniom i uczestniczącym w nim osobom" (Klus-Stańska 2010). Dydaktyka kierująca się potocznością określana jest jako „pop-dydaktyka”, w której głosi się populistyczne hasła, podaje proste recepty i gdzie ,procesy dydaktyczne wiązane są przede wszystkim z takimi atrybutami, jak przyjemne doznania emocjonalne, rekreacyjność i interpersonalne ciepło" (Klus-Stańska 2010) - bez wymienionych na początku rozdziału atrybutów mądrości, wiążących się z podmiotowością (szukanie dróg poznania, wynikająca z nich moc sprawcza i wewnętrzna satysfakcja z odkrywania) oraz z wiedzą (nie - wiadomościami). Jak napisała Klus-Stańska, ,inercyjna niezmienność” pop-dydaktyki i jej ,instrumentalne znieruchomienie” ,wyrasta z typowego dla potocznego rozumienia wiedzy szkolnej przekonania, że jedyną [...] strategią jej 
poznania i opanowania jest uczestnictwo w przekazowym nauczaniu". W związku z takim podejściem do nauczania ,jedyną drogą «oswojenia» go jest czynienie go miłym, okraszonym akcentami przyjaznej emocjonalności, możliwie łatwo przyswajalnym. [...] Ta wersja pop-dydaktyki pozostaje skutecznie «nieprzemakalna» na wiedzę profesjonalną związaną z dydaktyką i zanurzona w tęsknocie za ciepłem emocjonalnym świata szkoły" (Klus-Stańska 2010).

Z drugiej strony, pop-dydaktyka to także ,populistyczny, totalizujący dyskurs dyscyplinowania dzieci i młodzieży. [...] Ten rodzaj dyskursu żeruje na typowej dla społeczeństw konserwatywnych sentymentalizacji przeszłego porządku społecznego i tęsknocie za «starymi, dobrymi czasami», gdzie zgodna z nostalgicznymi przywołaniami z przeszłości, budząca miłe skojarzenia szkoła jest utożsamiana z niepodważalnym autorytetem nauczyciela, twarzami uczniów pilnie w niego wpatrzonych i ich umysłach świattych co najwyżej «na miarę», za to pokornych w oczekiwaniu na więcej” (Klus-Stańska 2010).

Pojęcie potoczności w tym artykule zbliżone jest do tego, co Sternberg (2005) nazwał głupotą (foolishness) i przedstawił jako przeciwieństwo mądrości, podkreślając przy tym, że głupota nie wynika z braku inteligencji praktycznej czy życiowego sprytu (smartness). Jakkolwiek podał przykłady głupoty głównie z obszaru biznesu i polityki, to głupota, czy, delikatniej mówiąc, potoczność, może być analizowana także (jeśli nie przede wszystkim, biorąc pod uwagę jej skutki) w zakresie edukacji.

„Głupie” myślenie według Sternberga (2005) charakteryzują pewne fałszywe przekonania (sofizmaty, fallacies of foolishness): nierealistyczny optymizm („,nie ma się co martwić"), który uniemożliwia podejmowanie działań prowadzących do sensownych rezultatów; egocentryzm (,najważniejsza jest własna korzyść”), zwalniający z odpowiedzialności za własne działania wobec innych (osób i instytucji) i uwzględniający tylko własny (często doraźny) interes; poczucie wszechwiedzy (,ja wszystko wiem najlepiej”), powodujące utwierdzanie siebie i innych w potędze i prawomocności własnej sztywnej wiedzy, bez świadomości tego, czego się nie wie; omnipotencja („mogę wszystko”), związana z poczuciem władzy, często - ze stosowaniem przemocy (także symbolicznej) i manipulacji; poczucie nietykalności, związane z otaczaniem się pochlebcami i nieprzyjmowaniem krytyki. Jako podsumowanie ewentualnych skutków tych fałszywych założeń można by sparafrazować popularne powiedzenie: „Głupota ma krótkie nogi”. Rezultaty takiego myślenia łatwo przynoszą bowiem szybkie, ale krótkotrwałe korzyści.

Dla edukacji geograficznej ważny może być wymiar rozumienia/nierozumienia innych kultur na osi mądrość-potoczność, związany z umiejętnością (lub jej brakiem) uwzględniania w ocenach innego niż własny, wyrastającego z własnej kultury, sposobu myślenia. Innym przejawem mądrości wiedzy geograficznej może być zastosowanie wiedzy o procesach przyrodniczych w dostrzeganiu 
i analizowaniu otaczających procesów przyrodniczych. Ich rozumienie, a nawet świadomość niemożności prognozowania zjawisk i związana z tym postawa życiowa, może być przejawem naszej mądrości lub głupoty. Brak wiedzy o faktach $\mathrm{w}$ połączeniu $\mathrm{z}$ brakiem wiedzy proceduralnej i ignorancją $\mathrm{w}$ zakresie wiedzy o funkcjonowaniu innych kultur, ale także procesów przyrodniczych, może przynieść przerażające rezultaty - budowanie konfliktów (społecznych, politycznych, gospodarczych, religijnych, ekologicznych) czy, w ich wyniku, eskalacja przemocy (Sternberg 2005). Robert Sternberg jako przykład podaje działania polityków, którzy, udając, że mają wiedzę dotyczącą innych państw, mogą podejmować decyzje np. o wojnie, oparte na fałszywych mniemaniach i wydumanych zagrożeniach.

\section{„UCIECZKA OD MĄDROŚCI” W GEOGRAFII, JEJ SKUTKI I MOŻLIWOŚCI RATUNKU}

Przedstawione wcześniej rozumienie mądrości jako procesu poznawczego lub jako mocy sprawczej geografowi może kojarzyć się z celami edukacji geograficznej, które mają prowadzić właśnie do rozumienia zjawisk, do rozpoznawania ich przyczyn i przewidywania konsekwencji. Przywołuje stwierdzenia klasyków polskiej geografii, dla których geografia nie była nauką ograniczoną tylko do znajomości faktów, ale, zaznaczmy to wyraźnie - na ich podstawie - do rozumienia złożoności i różnorodności świata oraz do wychwytywania wzajemnych relacji między zjawiskami. Takie wielopłaszczyznowe przyglądanie się światu nie daje jednej „właściwej” odpowiedzi. Wymaga intelektualnego wysiłku. Rezultatem edukacji geograficznej mogłoby być lepsze „bycie” w świecie, poczynając od rozumienia funkcjonowania Ziemi jako systemu, poprzez podejmowanie czysto pragmatycznych (ale wcale nie płytkich, bo poprzedzonych analizą faktów, rozpatrywanych z różnych punktów widzenia) decyzji dotyczących codziennych działań w sferze materialnej (np. rozpatrywanie czynników lokalizacji), po ciekawość i chęć rozumienia specyfiki zjawisk przyrodniczych, innych kultur oraz poczucia się świadomym, odpowiedzialnym mieszkańcem Ziemi. W tym ujęciu geografia również może nawiązywać do trzeciego aspektu mądrości - dobra osobistego wynikającego z pogłębionej refleksji oraz wewnętrznie motywowanej ciekawości świata.

Wydaje się, że w krajach, w których przez jakiś czas zaniedbywano edukację geograficzną, np. w Wielkiej Brytanii, prowadzi się obecnie dyskurs, który, choć nie wprost, odwołuje się do założeń szkolnej geografii jako dziedziny wiedzy mogącej dać właśnie tak rozumianą mądrość. Wynika to z doświadczenia swego rodzaju geograficznej ignorancji, będącej wynikiem kształtu brytyjskiej edukacji w latach 80. i 90. XX wieku. Krytycy ówczesnej geografii w szkole zwracali 
uwagę na polityczne i ekonomiczne uwikłania tego nauczania, na jego płytkość, jednostronność i indoktrynacyjność, przejawiającą się m.in. w testach egzaminacyjnych i pytaniach z tzw. krótką odpowiedzią albo w pytaniach z odpowiedziami wielokrotnego wyboru (zgodnie z klasyfikacją Niemierki, najczęściej - wbrew terminologii - pojawia w nich się jedna prawidłowa odpowiedź), jakkolwiek problemy w nich poruszane (jak wszystkie ,ziemskie” problemy) wcale nie były jednoznaczne. Jeden z krytyków, zajmujący się edukacją geograficzną, będąc jednocześnie byłym nauczycielem w szkole średniej, stwierdził: „Brytyjskie nauczanie geografii dotyczy wszystkiego pod Słońcem - z wyjątkiem geografii. [...] Nowi uczniowie, którzy przyszliby do mojej klasy, wiedzieliby wszystko o zanieczyszczeniach, ale nic o rzekach i pogodzie" (Standish 2002). Zawartość programu szkolnego powtarzała (i narzucała), według niego, wartości i postawy (np. enwironmentalizm, zrównoważony rozwój, tolerancję kulturową) z Nowej Agendy (New Agenda). Oprócz tego była nastawiona na kształtowanie życiowych umiejętności (life skills - chodzi o umiejętności zwane u nas „kluczowymi”). Jakkolwiek nie da się zaprzeczyć, że wszystkie wymienione tu aspekty mają wartość wychowawczą, to bez wiedzy o procesach, jakie zachodzą na Ziemi, stają się indoktrynacyjne i narzucają jedyny sposób widzenia, nie pozwalając uczniowi na rozumienie zjawisk, samodzielność ocen i wniosków, na stawianie pytań i problematyzowanie rzeczywistości, na konstruowanie wiedzy, czyniąc go biernym intelektualnie i oczekującym na gotowe wnioski. Brytyjscy nauczyciele skupiali się nie na tym, by uczniowie rozumieli system ziemskich zależności, ale na mówieniu uczniom, jak myśleć i działać w relacji do otaczającego świata. Na przykład uczniowie byli nauczani, jak powinni postępować, by zredukować globalne ocieplenie albo jak wielonarodowe korporacje eksploatują mniej rozwinięte kraje (Standish 2002). Problem tkwił w tym, że te pozytywne, wydawałoby się, działania nie wynikały z wiedzy o procesach (tak przyrodniczych, jak i tych wynikających z funkcjonowania ludzi) zachodzących na świecie, ale były narzuconymi, gotowymi algorytmami postępowania, niewymagającymi myślenia, za to stając się swego rodzaju wierzeniami czy mitami, rozumianymi jako stereotypy „,kształtowane przez ludzkie pragnienia" (Ledzińska, Czerniawska 2011).

Znamienny jest tytuł książki dotyczącej nauczania geografii jako istotnego przedmiotu z punktu widzenia „spraw ziemskich”: Teaching Secondary Geography as if the Planet Matters (Morgan 2011). W nauczaniu geografii istotne jest zrozumienie kontekstów, w jakich odbywa się ta edukacja i w jaki sposób wpływają one na nauczane treści. Mądrość tu dostrzegana to nieoczywistość świata, doszukiwanie się głębszych znaczeń w poruszanych zagadnieniach i rozważanie

${ }^{1}$ „British geography teaching is about everything under the sun - except geography. [...] New pupils would come into my class who knew everything about pollution and nothing about rivers or weather". 
różnorodnych uwikłań wiedzy geograficznej (politycznych, społecznych, kulturowych), nawet w tak, na pozór, neutralnych ideologicznie zagadnieniach, jak zmiana klimatu (Morgan 2011).

W tekstach o obecnej reformie edukacji w Wielkiej Brytanii pojawia się idea wiedzy dającej moc (powerful knowledge - Young 2014b), która jest opozycyjna do pojęcia przemocy, jaką może rodzić posiadanie wiedzy połączone z dystrybuowaniem tylko pewnego jej rodzaju i tylko pewnym grupom ludzi, nawiązującej do Foucaultowskiej wiedzo-władzy (knowledge of power). Idea powerful knowledge w edukacji może według Younga przyczynić się do zredukowania nierówności w dostępie do wiedzy i w jej dystrybucji, a w konsekwencji do niwelowania nierówności społecznych czy raczej do obrony przed ich reprodukowaniem w ramach systemu nauczania (por.: Bourdieu, Passeron 1990). Jakkolwiek wiedza jest produktem społecznym, to jednak ma realną postać jako wiedza zawarta $\mathrm{w}$ akademickich dyscyplinach, gdzie jest magazynowana, przetwarzana i rozumiana przez społeczność badaczy. To właśnie jest wiedza pełna mocy - powerful knowledge - która daje szansę na wyjście poza doświadczaną przez uczniów codzienność i poza potoczność. Ta wiedza, będąca efektem akademickich badań, nie jest dostępna w domu, między kolegami czy w społecznościach, w których żyją uczniowie i właśnie dlatego dostęp do niej jest prawem wszystkich uczniów jako przyszłych obywateli, choć (i także dlatego że) jej poznanie wymaga wysiłku intelektualnego. Michael Young podkreśla znaczenie codziennego doświadczenia uczniów, ale zwraca uwagę na niezostawianie ich z tym doświadczeniem samych. Nie wspomaga to bowiem rozwoju poznawczego (Young 2014b).

Mówiąc o przyszłości brytyjskiej szkoły, Young (2014a) kreśli wizję Future 1, Future 2, Future 3. Te „przyszłości” opisywane przez badacza wydają się odpowiadać $\mathrm{w}$ przybliżeniu ideologiom edukacyjnym przedstawionym przez Kohlberga i Mayer (2000): Future 1 - transmisji kulturowej, polegającej na odtwarzaniu wiedzy zgromadzonej przez pokolenia, Future 2 - romantyzmowi, stawiającego ucznia z całym jego bagażem psychofizycznym w centrum kształcenia, Future 3 - progresywizmowi, wspomagającemu rozwój poznawczy i osobowościowy ucznia, traktując go jako samodzielny, myślący podmiot, konstruujący na podstawie dostarczonej wiedzy nową, adekwatną do rzeczywistości. Future 3 najbardziej odpowiada Sternbergowskiej mądrości.

Future 1 jest według Younga powrotem do XIX-wiecznej szkoły, kiedy to możliwe było gromadzenie całej wiedzy i ,użyczanie” jej poprzez nauczycielski przekaz uczniom. Jakkolwiek w filozofii Future 3, leżącej u podstaw proponowanych zmian, także podkreśla się znaczenie wiedzy akademickiej, to pełni ona tu inną rolę niż w Future 1. W dzisiejszych czasach ważne jest nie tylko „wiedzenie” (knowing) o czymś. Wiedza akademicka w szkołach, chociaż uczenie się jej (nie 
o niej) wymaga podejmowania wielkiego wysiłku, nie zawsze przynoszącego zamierzone efekty, według koncepcji Future 3 może stanowić filtr, dzięki któremu możliwe jest analizowanie i interpretowanie zdarzeń - zarówno tych obecnych, jak i tych dopiero przewidywanych. Te filtry wiedzy akademickiej umożliwiają pogłębienie myślenia, rozumienie różnych perspektyw i w związku z tym odejście od płytkiej potoczności (głupoty). Mogą stanowić bazę dla tego, co Sternberg nazywa mądrością. Dlatego Future $l \mathrm{w}$ postaci prostej transmisji wiedzy akademickiej nie ma racji bytu w szkole kształcącej ku przyszłości. Future 2 to podejście, które stawia ucznia w centrum zabiegów edukacyjnych. Głównym założeniem jest nabycie przez uczniów umiejętności (skills), umożliwiających im społeczne bycie w świecie. Ważna jest tzw. aktywność ucznia. Wiedza schodzi tu na dalszy plan, w związku z czym utrudniony może być rozwój poznawczy, samodzielne oceny zdarzeń i podejmowanie adekwatnych do nich działań. $F u$ ture 2 zbliżona jest do tego, co Klus-Stańska nazwała w polskiej rzeczywistości pop-dydaktyką. Stanowi potoczną, skarykaturyzowaną wersję konstruktywistycznego podejścia, tyle tylko, że nie wspomagającą konstruowania wiedzy, ale radosne bycie razem. W efekcie, pozostawia uczniów z wiedzą, która niewiele wykracza poza to, czego mogą się sami nauczyć, obserwując świat dookoła i powielając potoczne jego rozumienie.

Podejście Future 2 funkcjonuje (według Younga) w brytyjskich szkołach, gdzie „wyrównywano szanse”; w szkołach, do których uczęszczają przede wszystkim uczniowie spoza elit, podczas gdy Future 1 dominuje w szkołach elitarnych. Można by dopatrywać się tu swego rodzaju protekcjonalizmu w dystrybuowaniu różnych rodzajów wiedzy ludziom z różnych klas społecznych, co wbrew hasłom „wyrównywania szans” skutecznie blokuje dostęp do wyższej edukacji uczniom z nizin społecznych. Służy to (nawet wbrew intencjom) utrwalaniu zastanego porządku społecznego, odtwarzaniu i reprodukowaniu kultury (por.: Bernstein 1990; Bourdieu, Passeron 1990). Jest odwrotnością wiedzy dającej moc sprawczą (powerful knowledge - stanowi wersję Foucaultowskiej knowledge of power, wiedzy umacniającej władzę - tłumaczonej w polskiej literaturze jako „wiedzo-władza”. Dlatego Future 3, która uwzględnia wiedzę osobistą ucznia, ale przede wszystkim wspomaga jej przekonstruowanie na podstawie wiedzy akademickiej, może być drogą ku mądrości przyszłych obywateli egalitarnego społeczeństwa.

Chyba nieprzypadkowo koncepcję funkcjonowania Future $3 \mathrm{w}$ szkole przedstawiono na przykładzie edukacji geograficznej, przez długie lata zaniedbywanej w brytyjskich szkołach, a w konfrontacji z wydarzeniami we współczesnym świecie (zarówno politycznymi, społeczno-gospodarczymi, jak i przyrodniczymi), jak się okazało, niezbędnej. Edukacji, która z racji swojego holistycznego charakteru umożliwia niełatwą drogę do mądrości.

David Lambert przedstawia cele edukacji geograficznej, wychodząc od osobistych wizji nawiązujących do przedstawionego przez Sternberga pojęcia mą- 
drości, które polega na ciekawości świata, wspartej intelektualnie wartościową wiedzą geograficzną: „Zawsze chciałem obudzić uczniów intelektualnie, pomóc otworzyć im oczy i wyposażyć w wiedzę o tym, jak świat działa. Żeby to zrobić, potrzebujemy określonych zasobów i moim wybranym źródłem wiedzy była geografia"” (Lambert 2014; thum. T. Sadoń-Osowiecka). Powołując się na teorie Bernsteina, dotyczące edukacyjnych praw młodych ludzi, m.in. do indywidualnego rozwoju, włączenia społecznego i politycznej partycypacji oraz na ideę powerful knowledge Younga, Lambert stwierdza, że nieetyczne jest pozostawianie uczniów tylko z ich wiedzą osobistą, uniemożliwiając im szansę na wyjście poza własny krąg rozumienia (Lambert 2014), a tym samym uniemożliwiając im wyjście także poza własną klasę społeczną i pełny udział w życiu społecznym. Edukacja geograficzna może być drogą do mądrości w tym sensie, że czerpiąc z naukowych teorii, nie daje łatwych i doraźnych efektów, wymaga głębszego rozumienia, trudu zarówno ucznia, jak i nauczyciela. Jej konsekwencją może być wyjście nie tylko „poza dostarczone informacje”, ale i głębsze rozumienie świata - rozumiane jako dobro osobiste, lecz w rezultacie i niejako ,przy okazji” dające możliwość wyjścia poza własny krąg społeczny.

Taka edukacja wymaga współtworzenia programu nauczania przez nauczycieli geografii, traktowanych, podobnie jak uczniowie, jako podmioty edukacji; wykształconych w zakresie geografii, więc zdolnych podejmować decyzje dotyczące zawartości (treści) wiedzy geograficznej przeznaczonej dla uczniów. National Curriculum byłoby tylko bazą dla ich interpretacji, zawsze jednak opartą na wiedzy naukowej. By nadążyć za odkryciami i rozwojem dyscypliny, konieczne staje się ciągłe uaktualnianie przez nauczycieli wiedzy przedmiotowej, nie jako zbioru faktów przyjmowanych za pewniki, ale jako wiedzy umożliwiającej krytyczne myślenie, potrzebne np. przy włączaniu do programu modnych, ale czasem indoktrynacyjnych, teorii. Jako przykład takiej teorii Lambert podaje środowiskowy determinizm, mogący w skrajnych przypadkach doprowadzić np. do wniosku, że rozmieszczenie całej działalności gospodarczej człowieka jest zdeterminowane wartością temperatury powietrza.

David Lambert zwraca uwagę na wartość GIS w edukacji geograficznej, ale nie jako uczenie posługiwania się i tak powszechnie używanymi w pozaszkolnym życiu technologiami (np. GPS), co sprowadzałoby edukację tylko do praktycznego wymiaru, bez intelektualnego zaangażowania, możliwości rozwoju uczniów i pogłębiania wiedzy geograficznej. Ważniejsze jest zrozumienie, co to jest GIS, dlaczego się rozwija i w jaki sposób może być używany (nie tylko jako nawigacja) - GIS jako narzędzie służące zdobywaniu informacji o różnych zjawiskach

${ }^{2}$, ,I have always wanted to wake pupils up intellectually, help open eyes and equip them with knowledge about how the world, works'. To do this we need disciplinary resources and my chosen resource was geography". 
(np. analiza rozmieszczenia danych przestrzennych, takich jak np. transakcje kartami kredytowymi, co może prowadzić do budowania wiedzy o rozmieszczeniu sklepów, preferencjach klientów itp.).

Jednak dla Lamberta technologie cyfrowe nie mogą zastąpić wiedzy o tworzeniu map w rozumieniu bardzo tradycyjnym - za pomocą kartki papieru i ołówka. Cyfrowe mapy są dla ludzi czymś, co po prostu jest w smartfonie i odzwierciedla rzeczywistość; są rodzajem magii, bo w potocznym ujęciu trudno powiedzieć, skąd się wzięły i nikt nawet się nad tym nie zastanawia. Tymczasem gdzieś w podtekście tych map pojawia się pojęcie odwzorowania Mercatora. Ucząc tworzenia map przedstawiających ważne miejsca, krajobrazy, relacje przestrzenne, uczymy jednocześnie znaczenia GIS, ale równocześnie pokazujemy ograniczenia technologii cyfrowych w konfrontacji z realnym otoczeniem i jego percepcją. Praca nad mapą ujawnia znaczenie wyobraźni, spekulacji, propagandy - pokazuje, że mapy wcale nie są obiektywne. Jednocześnie uczeń poznaje prawa, konwencje i praktyki stosowane przy ich tworzeniu (siatki kartograficzne, odwzorowania, symbole, izolinie itp.). Taka wiedza wyrasta poza potoczność i codzienne zastosowania technologii cyfrowych oraz map służących tylko odnalezieniu drogi.

David Lambert, mówiąc o powerful knowledge w geografii, nie ogranicza jej tylko do wiedzy istotnej i adekwatnej (dla kogo? i dlaczego?) zdefiniowanej przez „słuszne” i współczesne teorie. Nowoczesność edukacji nie polega na stosowaniu tylko „nowoczesnych” teorii czy „nowoczesnych” metod nauczania, które za jakiś czas i tak będą przestarzałe. Uaktualnianie wiedzy szkolnej nie polega na odrzuceniu dorobku nauki. Chodzi raczej o zmianę roli wiedzy budowanej na podstawie akademickich teorii; nie wiedzy o czymś - jako o faktach, ale wiedzy wynikającej ze sposobu myślenia. „Stare” teorie mogą służyć do tworzenia „architektury myślenia”. Badacz zwraca uwagę, że teorie, nawet te przebrzmiałe i rzekomo „martwe”, pokazują pewien sposób rozumowania i patrzenia na otaczający świat. Z tego względu nie widzi powodu, żeby nie używać ich w szkole jako narzędzi myślenia (np.: teorii przejścia demograficznego, teorii rozwoju rzeźby Davisa).

Innym aspektem jest potoczne rozumienia przez nauczycieli zasad dydaktycznych, rozumianych nie jako idee, ale jako praktyczne wskazówki odnoszące się do bardzo konkretnych faktów. Taką zasadą jest wychodzenie od osobistego doświadczenia ucznia, co powoduje niemożność podjęcia przez niektórych nauczycieli tematów, których nie da się doświadczyć osobiście ze względu choćby na miejsce i czas, w jakim zachodzą np. zjawiska geologiczne czy geomorfologiczne. Skrajnym przykładem jest tu postulat usunięcia z programu wiedzy o lodowcach, bo uczniowie tego nie doświadczyli, nie są w stanie sobie tego wyobrazić albo nie mają one dla nich znaczenia („lodowce nie robią nic z ich życiem”). Tymczasem geografia wymaga także abstrakcyjnego myślenia i uruchamiania za- 
sobów wyobraźni. A wiedza o lodowcach wiąże się ze zjawiskami dotyczącymi Londynu, w którym mieściła się szkoła - podtapiania dzielnic (ruchy izostatyczne), podnoszenia się poziomu morza (estuarium Tamizy).

Idee powerful knowledge w geografii pokazują jej znaczenie dla uczniów i nauczycieli w pogłębionym, nie potocznym, rozumieniu świata. Ich sens polega nie na zaspokajaniu tylko doraźnych interesów (ucznia i nauczyciela). Nie służą celom popisowym i szybkim „obiektywnym” efektom edukacyjnym. Nie pozostawiają także uczniów tylko z ich własnym myśleniem o świecie. Wiedza akademicka natomiast, wbrew pozorom, może pomóc w rozumieniu zjawisk dziejących się tu i teraz.

\section{PODSUMOWANIE}

Jako podsumowanie nawiązać można do geografii w polskiej szkole. Jakkolwiek przedstawione idee dotyczą geografii brytyjskiej, warto wziąć je pod uwagę także w polskiej rzeczywistości, gdzie edukacja geograficzna wydaje się ewoluować z Future 1 do Future 2, zagrażając utratą szansy na edukację zmierzającą ku mądrości.

Przy wszechobecnych hasłach głoszących kult „nowoczesnej” edukacji, polegający na wymierności bezdyskusyjnych, doraźnych efektów, traktujemy fakty jako istotę edukacji. Gubimy tradycyjne idee polskiej geografii. Uczniowie i nauczyciele, zajęci wypełnianiem kolejnych zadań, tracą umiejętność całościowego spojrzenia geograficznego, ,zmysłu geograficznego”, jak nazywał to specyficzne podejście do świata Nałkowski i mądrości, jaka kiedyś była charakterystyczna dla tego myślenia. Tymczasem brytyjscy geografowie otrząsnęli się już z ułudy „łatwego" uczenia, mówiąc o nauce myślenia geograficznego, prowadzącego nie tylko do wiedzy geograficznej, ale pośrednio - do mądrości jej używania.

\section{SUMMARY}

The author presents the idea of British school's reform in relations to categories of wisdom and foolishness by Sternberg or ordinariness. She refers to the discussion about geographical education in Great Britain. The aim of this paper is analyzing the idea of powerful knowledge and the visions of future British geographical education for arousing some reflections about Polish school geography. The conception of modern British geographers is like the conceptions of previous Polish geographers. But it seems that geographical education in Polish school, running for "modernity", goes away from these ideas. 


\section{LITERATURA}

Bauman Z., 1996: Socjologia, Wyd. Zysk i S-ka, Poznań.

Bernstein B., 1990: Odtwarzanie kultury, PIW, Warszawa.

Bourdieu P., Passeron J. C., 1990: Reprodukcja. Elementy teorii systemu nauczania, PWN, Warszawa.

Chalmers A., 1993: Czym jest to, co zwiemy nauka?: rozważania o naturze, statusie i metodach nauki: wprowadzenie do współczesnej filozofii nauki, Wyd. Siedmioróg, Wrocław.

Csikszentmihalyi M., Rathunde K., 1990: Psychology of wisdom: evolutionary interpretation, [w:] R. Sternberg (red.), Wisdom: Its Nature, Origins, and Development, Cambridge University Press, Cambrigde-New York-Melbourne, 28-48.

Hołówka T., 1986: Myślenie potoczne. Heterogeniczność zdrowego rozsądku, PIW, Warszawa.

Klus-Stańska D., 2010: Dydaktyka wobec chaosu pojęć i znaczeń, Wyd. Akad. ŻAK, Warszawa, $58-86$.

Kohlberg L., Mayer R., 2000: Rozwój jako cel wychowania, [w:] Z. Kwieciński (red.), Alternatywy myślenia o edukacji, Instytut Badań Edukacyjnych, Warszawa.

Lambert D., 2014: Subject teachers in knowledge-led schools, [w:] M. Young, D. Lambert, C. Roberts, M. Roberts, Knowledge and the Future School, Bloomsburry Academic, London, 160.

Ledzińska M., Czerniawska E., 2011: Psychologia kształcenia. Ujęcie poznawcze, Wyd. Nauk. PWN, Warszawa, 88-90.

Morgan J., 2011: Teaching Secondary Geography as if the Planet Matters, Routledge, London.

Morgan J., 2013: What do we mean by thinking geographically?, [w:] D. Lambert, M. Jones, Debates in Geography Education, Routledge, London-New York.

Standish A., 2002: Constructing a value map, http://www.spiked-online.com/newsite/author/ Alex\%20Standish/P20, 12 November 2002 [dostęp: 20.05.2008].

Sternberg J. R., 1990: Understanding wisdom, [w:] R. Sternberg (red.), Wisdom: Its Nature, Origins, and Development, Cambridge University Press, Cambridge-New York, 4.

Sternberg J. R., 2005: Foolishness, [w:] R. Sternberg (red.), Wisdom: Its Nature, Origins, and Development, Cambridge University Press, Cambrigde-New York-Melbourne, 338-344.

Takahashi M., Overton W. F., 2005: Cultural Foundation of Wisdom. An Integrated Developmental Approach, [w:] R. Sternberg, J. Jordan (red.), A Handbook of Wisdom. Psychological Perspectives, Cambridge University Press, Cambridge-New York.

Young M., 2014a: Knowledge, curriculum and the future school, [w:] M. Young, D. Lambert, C. Roberts, M. Roberts, Knowledge and the Future School, Bloomsburry Academic, London.

Young M., 2014b: Powerful knowledge as a curriculum principle, [w:] M. Young, D. Lambert, C. Roberts, M. Roberts, Knowledge and the Future School, Bloomsburry Academic, London. 